\begin{tabular}{lllllllllllllllllllllllllllllllll}
\hline$R$ & $E$ & $V$ & I & S & T & A & D & E & E & S & T & U & D & I & O & S & I & N & T & E & R & N & A & C & I & O & N & A & L & E & S
\end{tabular}

\title{
South America, the Bush Foreign Policy and the Future of American Hegemony
}

Conferencia dictada por el Dr. John E. Rielly, en el Instituto de Estudios Internacionales, Universidad de Chile, el 15 de julio de 2005.

It is a great pleasure to return to this platform at the University of Chile where I have had the pleasure of lecturing before. I want to thank the Director for the kind invitation and thank you all for coming. It has been my good fortune to have visited Chile regularly since June of 1964, now forty years ago. Interest in Chile remains high in the United State, and the American role in Chile in the twentieth century continues to generate passionate debate-as readers of Foreign Affairs journal have been reminded us in recent months.

My subject today is South America, the Bush foreign policy and the future of American hegemony. I will comment briefly on the overall priorities of the Bush foreign policy; second, on the Bush policy in relation to South America, especially Brazil, Argentina and Chile; and then conclude with some comments about the future of American hegemony.

As we know, the strategy of containmed and deterrence which shaped US policy for almost half a decade became no longer relevant after the disappearance of the Soviet Union in 1991. After the terrorist attacks on New York and Washington on September 
11, 2001, President George W Bush decided, like President Franklin

Documentos

D. Roosevelt after the attack on Pearl Harbor in 1941, that some drastic overhaul of US strategy was needed to meet the new threat posed by Islamic terrorism. The main outlines of this strategy are known to most of you: 1 . The policy of preemptive unilateralist military attacks on potential enemies-whether state or non-state actors; 2. A willingness to use force without the sanction of the UN Security Council or any other multilateral organization; and 3. An assertion that "the overlap between states that sponsor terrorism and those that pursue weapons of mass destruction compels us to action".

The latter assertion would become the justification for the attack on Iraq. We know that both of those assumptions were unsubstantiated or outright false, that there is no convincing evidence that Iraq has nuclear weapons or had close links to Al Quaeda. We now have seen the results of that military intervention: Saddam Hussein has been removed from power, the US has not suffered any new major terrorist attacks at home, a prolonged and bloody insurgency in Iraq continues, the US alienated some of its closest allies, and the US has come to be regarded in much of the world, including in South America, as an international pariah.

One further consequence of the Iraq obsession is that it has led to a policy of "benign neglect" toward South America. Like the Vietnam issue from 1965 to 1969, the Iraq issue has pushed aside all other issues for the past three years. With the second term of the Bush administration, there are already signs that this may change. Both the President and the new Secretary of State have made extensive visits to Europe in February and committed the US to renew its priority to relations with the EU and NATO Europe.

Secretary of Defense Rumsfeld visited Argentina in March. Secretary Rice made a well received visit in April to Brazil, Chile and Colombia. So issues other than Iraq may receive renewed attention during the second Bush term. While the President and other top officials may not have abandoned their unilateralist dreams, event-particularly the disastrous Iraq occupation- have compelled them to move in a multilateral direction, if the label "benign neglect" is accurate, characterization of US policy toward South America during the previous four years, certainly in some 
countries, Argentina for example, the neglect may not have so benign. In most of South America since the beginning of the $21^{\text {st }}$ century, there has been a strong backlash against the Washington Consensus, the view that the ultimate guide to economic and social progress in the rapid liberalization of the economy and the reduction of government influence. It is now clear that whatever the advantages of this policy prescription, the conditions were not in place for its successful implementation in a number of countries. In some cases, fragile government structures proved ill equipped to accommodate and sustain liberalizing policies. In others, regulatory frameworks and oversight mechanisms were obviously deficient. Adherence to the rule of law was uneven at best. And corruption added another obstacle. As a result you have populist governments today in Brazil, Argentina, Uruguay and Venezuela.

How has this attitude of benign neglect affected Argentina, Brazil and Chile? When, following the Peronist coup against President de la Rua in December 2001, Argentina collapsed and rapidly deteriorated into third world conditions, the Bush government did nothing to help avoid the disaster that followed. Ignoring the remarkable economic performance of Argentina in the 1990s, Treasury Secretary Paul O'Neill publicly scoffed and encouraged a negative hard line approach by the IMF. Because the problems facing Argentina-staggering foreign borrowing and indebtedness, profligate spending by the Menem government and the provinces, widespread corruption, weak savings rate, capital flight, an excessively prolonged link of the peso to the dollar-because these were problems caused primarily by Argentines governments, it is not clear that any outside help could have prevented the crisis. But it might have ameliorated it-had the assistance been timely and relevant.

It is therefore not surprising that President Kichner has resisted the pressure of the IMF to give priority to creditors, and has instead focused on internal economic recovery. Nevertheless when President Kirchner negotiated an agreement with the IMF in September 2003, the US supported this. When he suspended the agreement in August 2004, and renegotiated it in early 2005 at considerable cost to foreign bondholders, the US was not enthusiastic. Although Argentina has certainly not recovered its middle class standard of living, Argentina's $8 \%$ growth rate of the past two years is impressive. 
While the US government at one point anointed the Menem government as "non-NATO ally", the Kirchner government has been understandably cool toward the US. It declined to join the "coalition of the willing" in Iraq, and continued to develop warm relations with Cuba as well as with Chavez Venezuela. At the same time, it agreed to cooperate with the US in closer monitoring of potential terrors activity centered near the ArgentineParaguayan-Brazilian border. Secretary of Defense Rumsfeld's visit to Argentina in March of this year indicated increased attention to the country as Argentina prepares to host the Summit of the Americas in November of this year. There has also been greater recognition of Argentina's valuable role in providing military forces for five current UN peacekeeping missions.

Brazil has undoubtedly fared better during this period of benign neglect. The arrival of a left wing Brazilian government headed by long time labor leader at first generated considerable apprehension not only in Bush's Washington but also in New York. Surprisingly, relations have proceeded remarkably well. Presidents Lula and Bush appear to get on well personally. The Bush government supported the IMF agreement negotiated with Brazil. It has continued to be pleasantly surprised when the Lula government cut the budget deficit by $3 / 4$ since coming to power in January 2003, representing only $2.5 \%$ of GDP in 2005. This contrast with the US, which saw the budget surpluses of the last Clinton years disappear and be replaced by 400 to 500 billion dollar deficits. In 2004 Brazil had a trade surplus of 11.7 billion dollars, while the US has trade deficit of almost 500 billion. Between January 2003 and June 2005, the Brazilian real climbed 48\% against the dollar. During the first four years of the Bush administration the US dollar declined between 40 and 50\% against the Euro. Of course, to curtail inflation, Brazil must retain high interest rates that have recently reached $12 \%$ thereby threatening to slow economic expansion. High interest rates also favor the affluent segment of the population and therefore hinder efforts to reduce the continuing serious social and economic inequality in the country.

During the last five years, India, China and Brazil have emerged as strong regional powers. By 2005, these countries had discovered that because of the difficulties encountered in Iraq, Washington could be opposed effectively without incurring unacceptable costs. 
Thus Brazil has taken measures which the US opposed. Brazil's trade agenda gives priority to Mercosur, not to the Free Trade of the Americas Agreement its industrial policies have sometimes negatively impacted western pharmaceutical companies, as most recently the measures taken against Abbott Laboratory, threatening to ignore patents and produce generic drugs for AIDS patients.

Yet the Bush government has been noticeably more relaxed than some of Brazil's neighbors about its efforts to expand its hemispheric and its global role. The US has not protested Brazil's efforts to develop closer ties with the European Union, with China and India, to sign agreements with Korea and Japan, to host a Latin American-Arab summit meeting as well as to seek a seat on the Security Council.

Indeed, the US has supported Brazil's bid to acquire a permant seat at the UN Security Council. The participation of Brazilian troops in peacekeeping efforts in Haiti is widely appreciated. While differing on the FTAA issue, the US has not exerted intense pressure on the issue. While understandably curious about Brazil's expressed desire to produce enriched uranium, the Bush government has refrained from public denunciation. The high profile and highly successful visit of Secretary of State Condoleezza Rice to Brasilia in April, marked by strong praise for Brazil's democracy and strong public support for Brazil's aspirations for a UN Security Council seat, indicates that benign neglect is no longer an accurate description of current American policy toward Brazil.

One country where the term benign neglect does not apply during the last four years is Chile. Here the Bush Administration successfully concluded the negotiations begun earlier to sign and implement a US Chile Free Trade Agreement. It was signed in June 2003 and the implementation began in January 2004. Afterward, Chile's already impressive economic growth accelerated and total foreign direct investment increased from 2.5 billion dollars in 2003 to 7,1 billion in 2004. Exports in 2004 rose to 32 billion dollars, leaving Chile with a 9 billon dollar trade surplus. Chile's success of course is due less to US influence than to wise Chilean policies since 1990, which have featured prudent investment and spending policies, liberalization of the economy, a hospitable climate for foreign investment, strict adherence to the rule of law, and the highest degree of transparency in governmental 
practice in the hemisphere. Above all, its success is due to the replacement of the sharp ideological divisions which tore Chile apart in the 1970s and 1980s by a consensus-building politics that has made Chile a model of democratic development worldwide. The refusal of the Chilean government to support the Bush Administration on Iraq was deeply resented at the time. But by April of this year, following the successful visit to Chile of Secretary Condoleezza Rice, the US wasprepared in the end to support a Chilean candidate for Secretary General of the OAS, despite having its own preferred candidate. In late May, José Miguel Insulza was sworn in as Secretary General and received a few days later at the White House by President Bush. Despite continued widespread opposition in Chile to US policy on Iraq, official relations between the US and Chile have rarely been better.

Promotion of democracy has been highlighted as a high priority goal of the Bush Administration during both the first and second terms. In his second inaugural address, President Bush stated than "it is American policy to seek and support the growth of democratic movements in every nation and culture". The greatest good is "ending tyranny in the world". Yet it is not entirely clear that this policy was consistently applied in Latin American during the past four years. When a coup was launched in 2002 in Venezuela against the demagogic but duly elected President Hugo Chavez, the US quietly encouraged the coup even if it was not directly involved. And the US clearly played a direct role in securing the hasty exit from Haiti of President Aristide, a totally incompetent but elected demagogue. Although the Bush government continues to be outraged by Chavez behavior, it has been reluctant to exert decisive power against him. The countries that have maintained normal relations with Chavez Venezuela, like Brazil, Argentina and Chile, have not seriously damaged their relations with Washington.

I would now like to turn to the question of the future of American hegemony. Although it is too soon to make any definitive judgment about the final success or failure of the Iraq intervention, there is strong evidence that the current trend of the occupation will shorten the duration of American hegemony.

In retrospect it is hard to fathom why the Administration did not anticipate the requirements for the post military occupation of Iraq. We apparently did not anticipate continued internal opposition, 
let alone a violent and tenacious widespread insurgency. We did not prepare and recruit an experienced civilian administrative corps, but instead relied on young military volunteers who were trained for fighting wars, not for admisterting post-military occupations.

Nor is our occupation experience in Iraq an exception. The US has long been involved in post military occupations or nation building projects. We have had at least eighteen since the conquest of the Philippines in 1899. The overall record is not a pretty one. The cases of success-Germany, Japan and Korea, were all ones in which US forces came and stayed indefinitely. In Japan and Germany, we were not nation-building at all, but only religitimizing societies that had very powerful states. In most other cases, the US left nothing behind in terms of self-sustaining institutions, or made things worse by creating a modern army in a number of Latin American nations, but no rule of law.

Most Americans reject the notion that we are an empire. Americans have no taste for nation-building; we want exit strategies, not empires. We are prepared to spend 450 to 500 billion dollars a year on the defense bud, but starve the foreign policy and development agencies that are the natural institutions for running post-military occupations. What is the result? When we achieve a military victory and face an occupation, whom do we rely on? The American military. The military are trained for fighting wars, not post-military occupations. No wonder we often fail. Compare the American situation with that of the British Empire in the late $19^{\text {th }}$ and early twentieth centuries. Their imperial lands were ruled by administrators from the Colonial service, The India Service or the Africa Service. Who were these administrators? Often half of the senior people were graduates of Oxford and Cambridge. They were fluent in Arabic, Hindi or Swahili which they had studied at the university. They would go out to Arabia, India or Kenya with their families and remain for 20 or 30 years, often retiring there. After their military had subdued the natives, the civilian administrators took over and were always in charge, not the military. They built schools, roads, health systems and other modern infrastructure. Most important, they often development a modern public administration and often left behind functioning democratic institutions: They received England's highest honors-and coveted an OBE more than the title of CEO. 
In contrast, most Americans do not want to live abroad and particularly not in those hot smelly places that the English were prepared to tolerate. Of the four million Americans living abroad, three million live in Europe, Canada or Mexico. We have highly paid consultants from Mckinzie or Booz Allen that are prepared to go out three to six months and serve in specialized capacities. However, we have no equivalent of the British career administrative service. Since we are an imperial power-even if most Americans would deny it-and are likely to be faced with occupation responsibilities in the future, it is high time we trained and supported a qualified civilian administrative corps. Whether the Bush administration will give this a high priority is uncertain at best. In this respect, it is not unique among recent administrations. Until we do, the duration of our hegemony will be diminished.

In assessing the future of American hegemony, one must recognize the direct impact of American domestic policy on the world economy. Unlike most imperial powers of the past, which provided credit for their imperial outposts, The United States has become the world's largest debtor. Today we absorb $75 \%$ of the world's discretionary savings. We financed the Iraq war on a credit card. Our 450 -billion dollar budget deficit and 400-500 billion trade deficit have eroded the value of our currency. The dollar declined 40 to $50 \%$ against the Euro in the last three years, although it has appreciated about $10 \%$ in the last six months. The first George W. Bush administration expanded domestic government expenditures by $32 \%$ the largest expansion of the Federal government since President Lyndon Baines Johnson. Although the US economy remains the largest single economy, the share of world financial reserves held by the US is $6.2 \%$ not $62 \%$ but $6.2 \%$. And yet, the Bush administration is proposing a massive overhaul of Social Security which would involve borrowing an additional two trillion dollars over the next decade.

Before the recent veto of the European Constitution by France and the Netherlands, some central banks had already begun to shift some of their assets to the Euro. If leading OPEC nations were to shift oil sales out of dollars into Euros, it could lead to a crash of the dollar and a severe threat to the world economy. It is the continued profligacy by the Bush government-aided by a supine Congress-that poses the greatest threat to the future of American 
hegemony, greater than the possibility of a continued unilateralist foreign policy.

One obvious question yet to be addressed is whether US hegemony is likely to be replaced by another hegemon in the next two decades. This is unlikely in my view. However, the preeminent position of the US is likely to erode in the economic field-given the growing power of china, the European Union and to some extent India. China is the favorite candidate to succeed the US as the dominant hegemon of the $21^{\text {st }}$ century. This country's dramatic economic surge of the past two decades-averaging almost ten per cent per year, has already made it the dominant local power in Asia, and is rapidly reshaping the world economy. According to many experts, the Chinese economy could equal or surpass the US as the world's largest economy by the year 2025. China has a strong currency, a trade surplus not only with the US, but with Europe as well. China has financial reserves of over 600 billion dollars and is one of the two largest holders of US Treasury bonds. China is rapidly acquiring oil reserves and companies through out the world, including North and South America, and is today the largest customer for Iranian oil.

At the same time, China has been increasing it military budget by 10 to $12 \%$ a year for the past decade-and plans to continue this. Yet China's defense expenditures are a fraction of those of Japan and Korea, or the US and NATO Europe. If current trends continue, China's military capacity by 2025 will still be dwarfed by that of the US.

Another uncertainty in regard to China is whether it will remain a unified country, or whether is will succumb to internal conflicts leading to territorial division. The steadily eroding legitimacy of the Communist Party, and the loosening of its grip on Chinese society, due to affluence and the impact to technology and mass communications, means that the future of China until the end of the century remains uncertain. Despite these challenges, China is certain to become the dominant power in Asia in the next several decades, substantially reducing American influence in Asia.

Until the recent defeat of the European Constitution in France and the Netherlands and the conflicts over the European Union budget that followed, it appeared that another competitor for predominance in the world economy during the next several 
decades would be the European Union. Europe's limited military capacity compared to that of the US has obscured the emergence of the European Union as a decisive challenger to the continued US dominance of the world economy. As journalist T.R. Reid had pointed out in his new book "The United States of Europe", the European Union already by 2005 has more people, more wealth, more trade and more clout in most international organizations than the US. Despite its recent modest decline, the Euro is still the world's strongest currency, a currency that could eventually replace the dollar as the world's principal reserve currency if Europe can recover from its current squabbles.

Whether the European Union will be able to sustain the momentum of the past decade is now in doubt. In addition to the veto of the Constitution, division remain on foreign policy issues; unemployment remains around ten percent and growth rates are faltering in several leading member states; and most important, Europe faces a staggering population decline if present demographic trends continue. So while Europe has quietly reduced worldwide American economic dominance in recent years, it is not likely to replace the United States as a world hegemon in the next several decades.

If both China and Europe are not likely to replace the US as the dominant hegemon in the near term future, what are the other major factors that will extend or curtail American hegemony in this century? Clearly the threat of terrorism by fanatical fundamentalist groups will continue to loom large, particularly that based on Islamic fundamentalism. The stated determination of the Bush administration to engage itself on the Middle East, including the Israel Palestine issue, is a sign of progress, particularly if it works in combination with its European NATO partners. The increased attention to important global issues by the Administration, the Millennium Program for Africa, increased resources for fighting AIDS, debt relief for poor countries, and a renewed urgency about reform of the United Nations. Combined with a willingness to address many of these multilaterally, it certainly represents progress.

In conclusion, while I have alluded to the shift in the balance of economic power in the world, I do not overlook the many advantages that the US continues to have. Notwithstanding 
growing competition from Europe and China, the US remain attractive to foreign investors because it continues to have a strong research-based economy, flexible labor practices and newly strengthened companies following recent scandals. Unlike Europe, Japan, China and India, the US has a favorable population to land ratio. Its population continues to grow and is substantially younger than Europe or Japan. Most of the world's best universities are in the US. Unless inflexible implementation of the Patriot Act prevails, these universities will continue to attract some of the world's most talented and entrepreneurial people to our country.

Although the balance of world economic power is shifting toward Asia, I anticipate no comparable shift in the balance of military power in the short term. The overwhelming American superiority, based on a defense budget larger than the next twenty countries combined, is likely to continue for at least several decades-ends perhaps beyond. What is less certain is whether the American economy, given current policies and trends, can sustain this imperial force into the second half to this century. What threatens our hegemony is not so much a rival power as the threat of "imperial overstretch" that has undermined so many empires of the past. It is the domestic policies of this Administration that pose the greatest threat to long term American hegemony, not the unilateralist foreign policy of the first George W. Bush government. As indicated, because of events, there are already strong signs that the second Bush government is moving in a more multilateral direction on security issues. Rather than implementing "regime change" in Iran, it is working in tandem with the leading European nations in negotiating with Iran. Rather than implementing "regime change" in North Korea, it is participating in multilateral negotiations involving China, Japan, Russia, and South Korea. One additional reason for this change-and it is not the only reason-was stated by Robert Kagan, the conservative scholar who has strongly supported the Administration's policy on Iraq and whose book "Of Paradise and Power" has had enormous impact on policymakers on both sides of the Atlantic.

He stated that the Bush policy of the first term would have to change, if for no other reason than the American people will not long support a policy that is viewed as illegitimate by their closest democratic allies. As indicated earlier, the Bush administration may 
be beginning to understand this lesson. Because there is little evidence that they understand the danger of imperial overstretch, the duration of American hegemony will be in doubt. 